\title{
Huitlacoche yield in some maize varieties in the Mediterranean region of Turkey
}

\author{
Mehmet AYDOĞDU ${ }^{1 *}$
}

\begin{abstract}
Huitlacoche is the Aztecs name given to the smut galls on ears of maize caused by the pathogenic plant fungus Ustilago maydis [(DC) Corda.)]. It is known as maize mushroom, and it has been considered a delicacy and in Mesoamerica. The aim of the present study was to determine the responses of some maize varieties to the growth of the fungus in order to evaluate the prospect production of these smutty ears as a maize mushroom. A 2-year study was conducted in the Mediterranean region of Turkey in 2010 and 2011. Inoculations were performed by injecting inoculum into the ear through the silk channel of plants in plots. Each treatment had control plots. Average ear-gall (huitlacoche) severity and incidence of all the varieties were at the rates of 4.0 and $41.6 \%$, respectively. However, the highest severity of ear-gall (6.5) and incidence (60.6\%) were found in Karadeniz Yıldızı flint maize variety; colossal smutty ears were formed in the maize cultivars. This study showed that certain maize cultivars (flint corn and dent corn) can be used efficiently in the production of huitlacoche.
\end{abstract}

Keywords: maize; smutty ears; edible mushroom; U. maydis.

Practical Application: Raise awareness around the world about huitlacoche production.

\section{Introduction}

$U$. maydis is a devastating disease of maize when certain environmental conditions favor fungal development. However, in parts of central Mexico, smut galls on ears of maize are an edible delicacy and are designated as maize mushrooms, Mexican truffles, or maizteca mushrooms, an important food source in Mesoamerica (Valverde et al., 1993). Maize ears with galls have been picked up from naturally infected plants and eaten by people in Mexico and Latin America since the times of the Aztecs, who named it cuitlacoche (Kennedy, 1989). Huitlacoche or cuitlacoche comes from the word Nahuatl (the language of the Mexicas or Aztecs) "cuitlacochin" or "cuitlacuchtli" that means "degenerate corn on the cob" (Simeón, 1977; Sahagún, 1989; Juárez-Montiel et al., 2011).

Proximate composition of huitlacoche is $88-94 \%$ dry matter, 3-6\% ash (dry basis), $7-12 \%$ protein, and 2-5\% lipids (Valdez-Morales et al., 2010). The nutritional value of this mushroom has great importance for human diet. Protein content is similar or sometimes higher than that of other edible mushrooms. Therefore, huitlacoche may be used as an alternative protein source for vegetarian diets. Huitlacoche contains almost all essential amino acids, and lysine (6.3-7.3 $\mathrm{g} / 100 \mathrm{~g}$ protein) is one of the most abundant. Serine, glycine, aspartic, and glutamic acid collectively account for 44.3 to $48.9 \%$ of total amino acids. The high content of essential fatty acids also suggests that huitlacoche has a high nutritional value; some important fatty acids are oleic and linoleic acids (54.5 to 77.5\%). Huitlacoche has also been characterized as a high-quality nutraceutical food and an attractive ingredient to enrich other foods, mainly due to its extraordinary flavor and exceptional quality (Valverde \&
Paredes-López, 1993; Vanegas et al., 1995; Valverde et al., 2015). Most of total dietary fibre, $\beta$-glucans, and total free sugars values were higher than those reported for other edible mushrooms. The high concentration of antimutagenic substances appears to be an asset of this culinary delicacy (Valdez-Morales et al., 2010). Aflatoxin, ochratoxin, and zearalenone were not found in huitlacoche (Valverde \& Paredes-López, 1993).

Apart from these mycotoxins, Martínez-Flores et al. (2008) reported that after storage, there was no major change in the amino acid content of huitlacoche. The mushrooms kept their appearance, color, and weight better when stored at $3^{\circ} \mathrm{C}$ on the ear. Ethylene production by huitlacoche was not detected in the postharvest study of huitlacoche. Monroy-Gutiérrez et al. (2013) emphasized that under refrigeration the shelf life of huitlacoche was extended up to 30 days.

Huitlacoche is sold during the rainy season in the open-air markets of central Mexico. Over the years more than $90 \mathrm{Mg}$-sized huitlacoche have been canned by Mexican food processors (Valverde, 1992). About 400-500 tons of huitlacoche are sold annually during July and August in markets in Mexico City (Villanueva, 1997; Pataky \& Chandler, 2003). It is also processed by at least six companies that sell the specialty mushroom canned or lyophilized. Interest in producing $U$. maydis as a specialty mushroom in the U.S. has recently increased due to an emerging acceptance of huitlacoche by North American consumers, who view it as a gourmet food item that is part of a growing market for haute Mexican cuisine (Pataky \& Chandler, 2003). In the United States, fresh and frozen huitlacoche are sold for as much 
as $\$ 20 / \mathrm{kg}$. In spite of the potential value of huitlacoche, there are few reports on U. maydis cultivation (Valverde et al., 1993).

Reports of cuitlacoche as a cash crop have generally focused on gleaning naturally infected ears from fields, but they have not considered the production of cuitlacoche as an alternative crop (Pataky, 1991). The objective of the present study was to evaluate the yield of huitlacoche in different maize varieties (dent, flint, sweet, and popcorn).

\section{Materials and methods}

Galls (smutty ears) were obtained from smutty plants from maize-producing areas of Batı Akdeniz Agricultural Research Institute, located in the Mediterranean region of Turkey in 2009 and 2010. Potato dextrose agar (PDA, Oxoid) and 20\% carrot solution were used to get pure culture of $U$. maydis and for the propagation of sporidia (basidiospores), respectively. In the field trials, dent corn (Zea mays var. indentata) cultivars; Ada-523, Pioneer-3394 and Side; flint corn (Zea mays var. indurata) cultivars; Karaçay and Karadeniz Yıldızı; sweet corn (Zea mays var. saccharata) cultivars; Merit and Vega; and popcorn (Zea mays var. everta) variety (Antcin-98) were used as host plants.

\subsection{U. maydis isolation}

The galls were chopped and the chlamydospores (teliospores) were separated from the gall tissues by sieving through a tea strainer. Afterwards, teliospores were surface-sterilized by immersion in a $1 \%$ copper sulfate solution for 20 to $60 \mathrm{~h}$ and filtered through two layers of sterile cheesecloth not allowing the teliospores to pass through. Later, the teliospores on the cheesecloth were washed in three times with sterile distilled water, dried on sterile filter paper, and transferred to petri dishes containing PDA media supplemented with antibiotic (streptomycin sulphate). The dishes were incubated at $25^{\circ} \mathrm{C}$ for 4 to 5 days until sporidia (basidiospores) of $U$. maydis emerged. When sporidia were about a pinhead in size, they were taken from the cultures, transferred to 500 -mL Erlenmeyer flasks containing $20 \%$ sterile carrot solution, and incubated at $25{ }^{\circ} \mathrm{C}$ for 7 days. At the same time, the Erlenmeyer flasks were vigorously shaken for 1 to 2 min once or twice a week. Therefore, the inoculum required for the inoculations was obtained by allowing sporidia to multiply in the carrot solution (Tunçdemir, 1985).

\subsection{Preparation of inoculum}

Basidiospore suspensions in the Erlenmeyer flasks were stirred to get a homogeneous solution, and basidiospores were counted using a hemocytometer (Neubauer, Isolab, Germany). Basidiospore suspensions were diluted to appropriate concentrations using a sterile carrot solution and adjusted to $4 \times 10^{6}$ sporidia $\mathrm{mL}^{-1}$. Afterwards, in the same way, teliospore suspensions were arranged to $1 \times 10^{6}$ teliospores $\mathrm{mL}^{-1}$ and added into the basidiospore suspensions (Tunçdemir, 1985).

\subsection{Field trials}

Field trials were carried out in a randomized complete blocks design with a factorial arrangement with three replications. Each plot consisted of four $5 \mathrm{~m}$ long rows. The spacing between the rows was of $70 \mathrm{~cm}$ and $20 \mathrm{~cm}$ within the rows. Control plots were established for each treatment.

\subsection{Ecological properties of the research area}

The general soil texture of the research area was clayish and loamy. The area was fertilized with nitrogen, phosphor, and potassium at the rates of 180,80 , and $80 \mathrm{~kg} \mathrm{ha}^{-1}$, respectively. Field experiments were set up in the Antalya province of Turkey. The total monthly rainfall when the inoculations of the maize ears were performed in August of 2010 was $4.2 \mathrm{~mm}$, whereas no measurable rainfall was recorded in the same period in 2011. However, the average temperature and relative humidity in August 2010 and 2011 were $30.5^{\circ} \mathrm{C}, 59.1 \%$ and $29.6^{\circ} \mathrm{C}$ and $50.0 \%$, respectively (Turkey, 2013).

\subsection{Inoculation}

The ear inoculation method of Pataky et al. (1995) was modified as follows: $3 \mathrm{ml}$ of inoculum $(3 \times$ $10^{6}$ sporidia $\mathrm{ml}^{-1}+1 \times 10^{6}$ chlamydospores $\mathrm{ml}^{-1}$ ) were injected into the ear of each plant using a hypodermic syringe 3 days after silk emergence. Inoculations of the ears were performed on August 3rd and 21st in 2010 and on August 15th and 27th in 2011.

\subsection{Huitlacoche assessments}

Ear gall(huitlacoche) severity and incidence

Ear gall severity was calculated according to the 0 to 5 Johnson \& Christensen (1935) scale, where $0=$ very small galls ( $<2.5 \mathrm{~cm}$ in diameter); $1=$ small galls ( 2.5 to $5 \mathrm{~cm}$ in diameter); $2.5=$ medium galls ( 5 to $10 \mathrm{~cm}$ in diameter $)$; and $5=$ big galls ( $>10 \mathrm{~cm}$ in diameter). The ear gall incidence was calculated comparing the number of infected and non-infected ears.

\subsection{Statistical analysis}

The JMP statistical software (SAS Institute Inc., Cary, North Carolina, USA) was used to perform variance analysis. Differences between factors were determined by $\mathrm{F}$ test, and the mean values determined as different were grouped according to the $\mathrm{LSD}_{0.05}$ test (Düzgüneş et al., 1987).

\section{Results}

The average size of the galls varied from 1.0 to $10.7 \mathrm{~cm}$ diameter. In the ears, the ovaries and glumes were smutted. Sometimes, the entire pistillate inflorescence was converted into a huge $(16.5 \mathrm{~cm}$ diameter) smut gall due to severe infection of $U$. maydis on the susceptible flint corn variety (Karadeniz Yildiz1). Interactions of the year, variety, and year $\mathrm{x}$ variety were significant $(\mathrm{p}<0.01)$ (Table 1.2 and 3 ).

The lowest ear gall incidence (EGI) (10.0\% and 21.6\%) was found in the Antcin-98 (popcorn variety) in both years. However, the highest EGI values, in 2010 and in $2011,44.6 \%$ and $83.3 \%$, were detected in Karadeniz Ylldizı (flint corn variety) and Side (dent corn variety), respectively (Table 2 ). 
In both years, the highest $(3.9,9.1)$ and lowest $(1.5,2.2)$ ear gall severity (EGS) was detected in Karadeniz Ylldizı (flint corn variety) and Antcin-98 (popcorn maize variety), respectively. The average EGS over the two-year experiments conducted on all maize cultivars was 4.0 (Table 3 ).

\section{Discussion}

The average EGI values of Merit and Vega (sweet corn cultivars) in 2010 were 26.6 and $23.3 \%$, whereas the values in 2011 were 38.3 and $30.0 \%$, respectively (Table 2 ). However, du Toit \& Pataky (1999a), studying some sweet corn cultivars, reported average incidence of ears with galls of $50 \%$ for the hybrid Dazzle, 36\% for Frontier, 26\% for GH 2690, and 6\% for Punchline, in 1996. The authors also reported an average incidence of $44 \%$ for the hybrid Dazzle, 31\% for Frontier, 17\% for GH 2690, and 26\% for Punchline in 1997., Similar results were found in sweet corn cultivars by some other authors (Pataky, 1991; Valverde et al., 1993).

In the present study, the highest EGS was found in Karadeniz Yildızı (flint corn cultivar), whereas the lowest EGS was found in Antcin-98 (popcorn variety) (Table 3). Since it had more severe smut gall on its cobs, Karadeniz Ylldizı was more vulnerable to infection of $U$. maydis than the other cultivars. However, the cobs of Antcin-98 were less affected by the fungus than the others. In the present study, among the cultivars, the EGS values of huitlacoche was ranked according to their size (from largest to smallest) as follows: Flint, dent, sweet, and popcorn, respectively. It can be concluded that the bigger the cobs, the higher the development of large smut galls on them; flint

Table 1. Variance analysis of ear gall incidence and severity.

\begin{tabular}{cccc}
\hline Source & DF & $\begin{array}{c}\text { Ear gall } \\
\text { incidence }\end{array}$ & Ear gall severity \\
\hline Year & 1 & $7701.3^{* *}$ & $98.9^{* *}$ \\
Replication[Year] & 4 & 16.7 & 0.1 \\
Variety & 7 & $1570.1^{* *}$ & $14.2^{* *}$ \\
Variety x Year & 7 & $343.3^{* *}$ & $7.2^{* *}$ \\
Interaction & & & \\
Error & 28 & 18.5 & 0.1 \\
CV (\%) & & 10.3 & 8.1 \\
\hline
\end{tabular}

**: Significant at $\mathrm{P}<0.01$ and dent corn varieties showed higher EGS values than the others. These results corroborate the earlier findings of Pataky \& Snetselaar (2006). These authors stated that incidence of smut infection was greater than 50\% in 1976 in several areas of Germany where hybrids derived from European flint corn were prevalent. Similarly, in a study conducted by Bojanowski (1969) in Poland, U12 (a flint corn inbred) was identified as susceptible to corn smut. However, Pataky \& Chandler (2003) reported that maximum yields of huitlacoche from male-sterile field corn hybrids were around $40 \%$ greater than those from sweet corn hybrids. Pataky (1991) stated that extremely susceptible genotypes may exist between dent, flint, floury, and other types of corn, and ear galls on these types of corn may be equally well suited for cuitlacoche production.

In addition, in the present study, the EGI of the cultivars ranged according to the hosts, and similar EGI responses were detected as EGS. The average EGS and EGI values of all cultivars in 2011 were higher than those in 2010. Year-to-year variation found in the present study could be explained as follows: it is known that environmental conditions can influence the development of diseases, in particular during penetration and infection of the host. Tunçdemir \& Iren (1980) reported that the most favorable temperature for development of corn smut ranges between $18{ }^{\circ} \mathrm{C}$ and $21^{\circ} \mathrm{C}$. In this regard, in 2010 , the average daily temperature on the inoculation day and on the ensuing day was $30.7^{\circ} \mathrm{C}$, whereas, in 2011 , it was $27.2^{\circ} \mathrm{C}$ (Table 4). Therefore, the difference in temperature may have adversely affected germination and penetration of the fungus in 2010. In addition, the environmental conditions in 2010 may have been favorable for the host. Kyle (1929) also emphasized that when environmental factors are in favor of the host during the maize growing season, smut infection levels are reduced. Moreover, in a two-year study conducted in Germany, Görtz et al. (2008) stated that in 2006, the frequency of kernel infected by Fusarium spp. ranged from $0.7 \%$ to $99.7 \%$, while in 2007 , the highest incidence of Fusarium ear rot was $64 \%$. The authors expressed that the year-to-year variability in the overall infection rate may be explained by significant differences in temperature and precipitation during the growth periods. Apart from these factors, plant nutrition can also affect smut infection. Aydoğdu \& Boyraz (2011) reported that nitrogen and farmyard manure could be important factors impacting severity of corn smut in

Table 2. Ear gall sizes and incidence of the cultivars after silk channel inoculation.

\begin{tabular}{|c|c|c|c|c|c|c|}
\hline \multirow[b]{2}{*}{ Maize varieties } & \multicolumn{2}{|c|}{2010} & \multicolumn{2}{|c|}{2011} & \multicolumn{2}{|c|}{ Mean } \\
\hline & $\begin{array}{l}\text { Gall diameter (cm) } \\
\text { (from min. to max.) }\end{array}$ & $\begin{array}{c}\text { Ear gall incidence } \\
(\%)\end{array}$ & $\begin{array}{l}\text { Gall diameter (cm) } \\
\text { (from min. to max.) }\end{array}$ & $\begin{array}{c}\text { Ear gall incidence } \\
(\%)\end{array}$ & $\begin{array}{l}\text { Gall diameter (cm) } \\
\text { (from min. to max.) }\end{array}$ & $\begin{array}{l}\text { Mean ear gall } \\
\text { incidence (\%) }\end{array}$ \\
\hline Ada-523 & $1.0-6.0$ & 28.6 & $1.0-12.5$ & 46.6 & $1.0-12.5$ & 37.6 \\
\hline Side & $1.8-10.2$ & 36.3 & $1.0-15.0$ & 83.3 & $1.0-15.0$ & 59.8 \\
\hline Karaçay & $2.5-5.9$ & 30.1 & $1.5-13.6$ & 68.3 & $1.5-13.6$ & 49.2 \\
\hline Vega & $1.0-10.1$ & 23.3 & $1.2-5.1$ & 30.0 & $1.0-10.1$ & 26.6 \\
\hline Antcin-98 & $1.1-5.2$ & 10.0 & $1.0-5.6$ & 21.6 & $1.0-5.6$ & 15.8 \\
\hline Average & $1.2-7.1$ & 28.9 & $1.2-10.1$ & 54.3 & $1.0-10.7$ & 41.6 \\
\hline
\end{tabular}

Year LSD $(0.01)=3.4$ Variety LSD $(0.01)=6.8$ Year x Variety LSD $(0.01)=9.7$. 
Table 3. Ear gall severity of the cultivars after silk channel inoculation.

\begin{tabular}{lccc}
\hline \multirow{2}{*}{ Variety } & \multicolumn{3}{c}{ Ear gall severity $^{*}$} \\
\cline { 2 - 4 } & 2010 & 2011 & Mean \\
\hline Ada-523 & $2.1^{* *}$ & 6.5 & 4.3 \\
Pioneer-3394 & 2.4 & 4.9 & 3.6 \\
Side & 3.3 & 8.6 & 5.9 \\
Karaçay & 2.0 & 6.3 & 4.1 \\
Karadeniz Yıldızı & 3.9 & 9.1 & 6.5 \\
Merit & 3.0 & 3.4 & 3.2 \\
Vega & 2.8 & 3.1 & 2.9 \\
Antcin-98 & 1.5 & 2.2 & 1.8 \\
Mean & 2.6 & 5.5 & 4.0 \\
\hline
\end{tabular}

Year LSD $(0.01)=0.2$ Variety LSD $(0.01)=0.5$. Year $x$ variety LSD $(0.01)=0.7 . *$ : The highest value of disease severity accepted was 10.0. ${ }^{* *}$ : Data are means of three replicates.

Table 4. Daily mean temperature of the research area during inoculations.

\begin{tabular}{cccc}
\hline $\begin{array}{c}\text { Inoculation } \\
\text { time in August } \\
(2010)\end{array}$ & $\begin{array}{c}\text { Daily average } \\
\text { temperature } \\
\left({ }^{\circ} \mathrm{C}\right)\end{array}$ & $\begin{array}{c}\text { Inoculation } \\
\text { time in August } \\
(2011)\end{array}$ & $\begin{array}{c}\text { Daily average } \\
\text { temperature } \\
\left({ }^{\circ} \mathrm{C}\right)\end{array}$ \\
\hline 3 & 29.8 & 15 & 27.2 \\
4 & 29.5 & 16 & 27.5 \\
21 & 32.0 & 27 & 27.6 \\
22 & 31.8 & 28 & 26.8 \\
\hline
\end{tabular}

Regional Meteorology Station, Antalya.

the field. Additionally, physiology and morphological structure of the host can also play an important role in development of the fungus. Since the maize cultivars evaluated have specific physiology and morhological features, different reactions against $U$. maydis were determined in the study. Pataky \& Richter (2007) underscored that husk leaves may affect silk dynamics and therefore indirectly affect smut infection. Pataky \& Chandler (2003) also emphasized that corn cultivars, isolates of U.maydis, and environmental factors affect gall maturity and size. A cultivar-trial in the Columbia Basin in the U.S showed marked differences in susceptibility to corn smut between field corn hybrids (Mohan et al., 2013).

Eighteen ear galls were harvested after inoculation, and the big ones varied from 220 to $312 \mathrm{~g}$ in Karadeniz Ylldızı, Karaçay (flint corn varieties) and Ada-523, Side (dent corn varieties). Nevertheless, smaller galls, maximum ranging from 6,10.1 and $5.6 \mathrm{~cm}$ diameter, were found in from Merit, Vega (sweet corn varieties) and Antcin-98 (popcorn variety), respectively. Pataky \& Chandler (2003) stated that the yield of huitlacoche and severity of ear galls are closely related. Valverde et al. (1993) reported that gall weight is related to ear size. However, establishing an ideal harvest time for the maize mushroom is crucial due to its vulnerable texture. Observing the huitlacoche development on the maize cultivars, following the silk channel inoculation, $18 \mathrm{~d}$ post-inoculation ear galls were harvested and weighed. Valverde et al. (1993) reported that the optimal huitlacoche harvest time varied from 17 to 19 days after inoculation between hybrids. However, Pataky \& Chandler (2003) stated that yield and quality of huitlacoche were optimal during a 1- to 2 -d harvest window, about $16 \mathrm{~d}$ after inoculation, and the quality of huitlacoche harvested 16 or $17 \mathrm{~d}$ after inoculation was acceptable.

The introduction of this food into the international market requires the development of techniques for massive year-long production (Valverde et al., 2015). In the present study, the silk channel inoculation method was efficiently used for the hutilacoche production. du Toit \& Pataky (1999a) reported that the silk channel method of inoculating for common smut is suitable to evaluate a limited number of lines or to induce ear galls for commercial production of huitlacoche. Pataky \& Chandler (2003) also stated that silk-channel inoculation methods developed to evaluate common smut resistance in maize can be used to produce huitlacoche commercially.

\section{Conclusion}

Too little is known about huitlacoche and its production commercially in Turkey and elsewhere, except for Mesoamerica and United States of America. However, commercial production of huitlacoche is carried out in some parts of Mexico. Gaining popularity as a maize mushroom in interntional cuisines such as US, Japan, and Europe, huitlacoche has been produced commercially in some sweet corn cultivars (Pataky, 1991; Valverde et al., 1993; du Toit \& Pataky, 1999a, b). The main purpose of the present study was to determine the yield of huitlacoche in dent, flint, popcorn, and sweetcorn varieties. In conclusion, flint and dent corn cultivars were found to be more suitable for huitlacoche production than the popcorn and sweet corn varieties, i.e., flint and dent can provide higher yield than the others and can be more efficiently used in huitlacoche production. It was also found that the ideal harvest time of this mushroom is $18 \mathrm{~d}$ post-inoculation. Harvesting it during this period of time can extand huitlacoche shelf life. Since huitlacoche has been gaining popularity in international cuisines, further studies are needed to promote its commercial production, storage, and trade.

\section{References}

Aydoğdu, M., \& Boyraz, N. (2011). Effects of nitrogen and organic fertilization on corn smut (Ustilago maydis (DC) Corda.). African Journal of Agricultural Research, 6(19), 4539-4543.

Bojanowski, J. (1969). Studies of inheritance of reaction to common smut in corn. TAG. Theoretical and applied genetics. Theoretische und angewandte Genetik, 39(1), 32-42. http://dx.doi.org/10.1007/ BF00283082. PMid:24435217.

du Toit, L. J., \& Pataky, J. K. (1999a). Effects of silk maturity and pollination on infection of maize ears by Ustilago maydis. Plant Disease, 83(7), 621-626. http://dx.doi.org/10.1094/PDIS.1999.83.7.621.

du Toit, L. J., \& Pataky, J. K. (1999b). Variation associated with silk channel inoculation for common smut of sweet corn. Plant Disease, 83(8), 727-732. http://dx.doi.org/10.1094/PDIS.1999.83.8.727.

Düzgüneş, O., Kesici, T., Kavuncu, O., \& Gürbüz, F. (1987). Research and trial methods (Statistics Methods- II). (Publ. No: 1021; Lesson Book, No: 295). Ankara: Faculty of Agriculture, Ankara University.

Görtz, A., Oerke, E. C., Steiner, U., Waalwijk, C., Vries, I. D., \& Dehne, H. W.(2008). Biodiversity of fusarium species causing ear rot of maize in Germany. In 3rd International FHB Symposium Szeged, Szeged, Hungary. 
Johnson, I. J., \& Christensen, J. J. (1935). Relation between number, size and location of smut infections to reduction in yield of corn. Phytopathology, 25, 223-233.

Juárez-Montiel, M., Ruiloba de León, S., Chávez-Camarillo, G., Hernández-Rodríguez, C., \& Villa-Tanaca, L. (2011). Huitlacoche (corn smut), caused by the phytopathogenic fungus Ustilago maydis, as a functional food. Revista Iberoamericana de Micologia, 28(2), 69-73. http://dx.doi.org/10.1016/j.riam.2011.01.001. PMid:21352944.

Kennedy, D. (1989). The art of Mexican cooking. New York: Bantam.

Kyle, C. H. (1929). Relation of husk covering to smut of corn ears. (U. S. Department of Agriculture Technical Bulletin, No. 120, pp. 1-7). Washington: United States Department of Agriculture. Retrieved from http://naldc.nal.usda.gov/naldc/download.xhtml?id=CAT86 200114\&content=PDF.

Martínez-Flores, A., Corrales-García, J. J., Espinosa-Solares, T., GarcíaGatica, P. G., \& Villanueva-Verduzco, C. (2008). Postharvest changes in the edible mushroom huitlacoche (Ustilago maydis (D.C.) Corda). Revista Chapingo Serie Horticultura, 14(3), 339-346.

Mohan, S. K., Hamm, P. B., Clough, G. H., \& du Toit, L. J. (2013). Corn Smuts. A Pacific Northwest Extension Publication, 647, 1-7. Retrieved from http://ir.library.oregonstate.edu/xmlui/bitstream/ handle/1957/40801/pnw647.pdf.

Monroy-Gutiérrez, T., Valle-Guadarrama, S., Espinosa-Solares, T., Martínez-Damián, M. T., \& Pérez-López, A. (2013). Effect of microperforation and temperature on quality of modified atmosphere packaged huitlacoche (Ustilago maydis). CyTA - Journal of Food, 11(4), 309-317. http://dx.doi.org/10.1080/19476337.2012.755712.

Pataky, J. K. (1991). Production of cuitlacoche [Ustilago maydis (DS) Corda] on sweet corn. HortScience, 26(11), 1374-1377. Retrieved from http://hortsci.ashspublications.org/content/26/11/1374.full. pdf + html.

Pataky, J. K., \& Chandler, M. A. (2003). Production of huitlacoche, Ustilago maydis: timing inoculation and controlling pollination. Mycologia, 95(6), 1261-1270. http://dx.doi.org/10.2307/3761926. PMid:21149027.

Pataky, J. K., \& Richter, P. M. (2007). Silk abscission in two sweet corn (Zea mays L.) hybrids that differ in susceptibility to common smut infection of ears. HortScience, 42(6), 1409-1412. Retrieved from http://hortsci.ashspublications.org/content/42/6/1409.full.pdf + html

Pataky, J. K., \& Snetselaar, K. M. (2006). Common smut of corn. The Plant Health Instructor. Retrieved from http://www.apsnet.org/ edcenter/intropp/lessons/fungi/Basidiomycetes/Pages/CornSmut.aspx.

Pataky, J. K., Nankam, C., \& Kerns, M. R. (1995). Evaluation of a silkinoculation technique to differentiate reactions of sweet corn hybrids to common smut. Phytopathology, 85(10), 1323-1328. http://dx.doi. org/10.1094/Phyto-85-1323.

Sahagún, B. (1989). General history of the things of New España (2nd ed.). Mexico: National Council for Culture and the Arts-Alliance Editorial Mexicana.

Simeón, R. (1977). Nahuatl language dictionary o Mexicana. México: 21st Century/ Our America.

Tunçdemir, M., \& Iren, S. (1980). Investigations on the bioecology of corn smut (U. maydis (D.C) Corda) in Samsun and its vicinity (Master thesis). Ankara University, Agriculture Faculty, Ankara.

Tunçdemir, M., (1985). The seminar of the diseases of wheat and maize. Ankara: Central Anatolia Forestry Research Institute.

Turkey. (2013). Meteorological data of Antalya province. Muratpaşa: Meteoroloji Genel Müdürlügü. Retrieved from http://www.antalya. mgm.gov.tr/tahmin-tum-merkezler.aspx.

Valdez-Morales, M., Barry, K., Fahey, G. C., Jr., Domínguez, J., Mejia, E. G., Valverde, M. E., \& Paredes-López, O. (2010). Effect of maize genotype, developmental stage, and cooking process on the nutraceutical potential of huitlacoche (Ustilago maydis). Food Chemistry, 119(2), 689-697. http://dx.doi.org/10.1016/j.foodchem.2009.07.015.

Valverde, M. E. (1992). Infecion studies of huitlacoche (Ustilago maydis) and dietary characteristics (Master thesis). Center for Investigation and Advanced Studies of the National Polytechnic Institute, Irapuato, Mexico.

Valverde, M. E., \& Paredes-López, O. (1993). Production and evaluation of some food properties of huitlacoche (Ustilago maydis). Food Biotechnology, 7(3), 207-219. http://dx.doi.org/10.1080/08905439309549858.

Valverde, M. E., Fallah Moghaddaml, P., Zavala-Gallardol, M. S., Patakyl, J. K., Paredes-Lopez, O., \& Pedersen, W. L. (1993). Yield and quality of huitlacoche on sweet corn inoculated with Ustilago maydis. HortScience, 28(8), 782-785. Retrieved from http://hortsci. ashspublications.org/content/28/8/782.full.pdf.

Valverde, M. E., Hernández-Pérez, T., \& Paredes-López, O. (2015). Edible mushrooms: improving human health and promoting quality life. International Journal of Microbiology, 2015(2015), 14 p. http:// dx.doi.org/10.1155/2015/376387.

Vanegas, P. E., Valverde, M. E., Paredes-Lopez, O., \& Pataky, J. K. (1995). Production of the edible fungus huitlacoche (Ustilago maydis): Effect of maize genotype on chemical composition. Journal of Fermentation and Bioengineering, 80(1), 104-106. http://dx.doi. org/10.1016/0922-338X(95)98187-P.

Villanueva, C. (1997). Huitlacoche (Ustilago maydis) as a food in Mexico. Micología Neotropical Aplicada, 10, 73-81. 